\title{
Yeast extract and prebiotic in pre-initial phase diet for broiler chickens raised under different temperatures ${ }^{1}$
}

\section{Vanessa Karla Silva ${ }^{2 *}$, Janaina Della Torre da Silva ${ }^{3}$, Rodrigo Antonio Gravena ${ }^{3}$, Rafael Henrique Marques ${ }^{3}$, Fabricio Hirota $\mathrm{Hada}^{3}$, Vera Maria Barbosa de Moraes ${ }^{3}$}

\author{
1 Projeto financiado parcialmente pela empresa Alltech do Brasil Agroindustrial Ltda. e pela FAPESP \\ 2 Departamento de Morfologia e Fisiologia Animal/FCAV-UNESP/Jaboticabal. \\ ${ }^{3}$ Departamento de Zootecnia/FCAV-UNESP/Jaboticabal. \\ * Bolsista CNPq.
}

ABSTRACT - The objective of this research was to evaluate the performance, carcass yield and intestinal morphometry of broiler chickens raised under different temperatures that received feed with or without yeast extract and prebiotic in the pre-initial phase. One thousand four hundred and forty one-day old male chicks were used, raised in different climate chambers. Feed with or without the addition of yeast extract and prebiotic was offered only in the pre-initial phase (1 to 7 days). From the eighth day on, every chick received the same feed, readjusted according to usual recommendations. A randomized complete experimental design was used in a $3 \times 2 \times 2$ factorial arrangement, consisting of three environmental temperatures (hot, comfort and cold) and two levels of yeast extract (with or without) and prebiotic (with or without). The performance of the birds was evaluated considering weight gain, feed intake, food conversion and viability at 42 days of age. Carcass yield and intestinal morphometry were also evaluated. Environmental heat impaired performance and carcass yield. Prebiotic inclusion in the pre-initial feed increased weight gain and enhanced food conversion of birds raised under hot conditions. The inclusion of products in the feed of broiler chickens raised in hot and cold environments has beneficial effects on chicken intestinal villi.

Key Words: carcass yield, heat stress, intestinal morphometry, mannanoligosaccharides, performance, Saccharomyces cervisiae

\section{Extrato de leveduras e prebiótico na dieta pré-inicial de frangos de corte criados em diferentes temperaturas}

\begin{abstract}
RESUMO - Objetivou-se nesta pesquisa avaliar o desempenho, o rendimento de carcaça e a morfometria intestinal de frangos de corte criados em diferentes temperaturas e que receberam na fase pré-inicial ração contendo ou não extrato de leveduras e prebiótico. Foram utilizados 1.440 pintos machos de 1 dia de idade, criados em diferentes câmaras climáticas. As rações, acrescidas ou não de extrato de leveduras e prebiótico, foram oferecidas somente na fase pré-inicial (1 a 7 dias). A partir do oitavo dia, todas as aves receberam a mesma ração, reajustada de acordo com as recomendações usuais. Adotou-se o delineamento experimental inteiramente casualizado em arranjo fatorial $3 \times 2 \times 2$, composto de três temperaturas de criação (calor, conforto e frio) e dois níveis de extrato de leveduras (com ou sem) e prebiótico (com ou sem). O desempenho das aves foi avaliado considerando o ganho de peso, o consumo de ração, a conversão alimentar e a viabilidade aos 42 dias de idade. Também foram avaliados o rendimento de carcaça e a morfometria intestinal. O calor ambiente prejudicou o desempenho e o rendimento de carcaça. A inclusão de prebiótico na ração pré-inicial aumentou o ganho de peso e melhorou a conversão alimentar das aves criadas no calor. A inclusão dos produtos na ração de frangos de corte criados em ambiente de calor e no frio tem efeito benéfico sobre as vilosidades das aves.
\end{abstract}

Palavras-chave: desempenho, estresse calórico, mananoligossacarídeos, morfometria intestinal, rendimento de carcaça, Saccharomyces cerevisiae

\section{Introduction}

The use of diversified diet for broiler chickens in the first week of age has been recommended by several nutritionists. This practice is justified by the fact that broiler chickens at that age have specific and different nutritional needs than in other phases, probably due to different gastrointestinal tract characteristics and their difficulty in digesting and absorbing some nutrients because of the rapid development. Thus, substances that 
have trophic action on intestinal mucosa may enhance the performance of chickens and provide better capacity for digesting and absorbing nutrients from the diet.

Yeast extract is a protein source derived from the cell content of live yeast. It is rich in nucleotides, inositol and glutamic acid. Nucleotides are used in human nutrition, mainly in diets for newborns, and act on gastrointestinal development, imune system functioning and intestinal flora maintenance. Uauy et al. (1990) observed that supplementation of $0.8 \%$ nucleotides promoted intestinal growth and maturation of young rats, with the increase in the villus height and crypt depth. Silva et al. (2009) evaluated the effect of yeast extract on the performance of broiler chickens and observed a better food conversion within the period from 1 to 21 days. Several studies have been carried out with another additive that deserves prominence in the scientific literature, the prebiotics (Albino etal., 2006; Oliveira etal.2007,2009; Godoi etal.,2008). It is known that the main form of action of the prebiotics is to favor the growth of benefic microbial populations, enhancing luminal conditions, anatomical characteristics of the gastrointestinal tract and immune system and also, in some cases, by enhancing the animal performance (Silva \& Nörberg, 2003).

Environmental variables may have effect, such as positive or negative, on the production of broiler chickens. High temperatures cause metabolic changes in animals, according to reports in the literature, which results in lower meat yields, specially breast, lower muscle mass gain and higher fat accumulation, that impair performance.

Considering the importance of the research of new additives that may enhance beneficial effects in the gastrointestinal tract and, therefore, enhance the performance indexes and carcass yield in thermal stress situations, the objective of this study was to evaluate the effects of including yeast extract or prebiotic in the pre-initial phase on performance, carcass yield and intestinal morphometry of chickens raised under different temperatures.

\section{Material and Methods}

The experiment was conducted in the experimental poultry house of the Department of Animal Sciences of São Paulo State University, Campus Jaboticabal, with 1,440 male chicks of Cobb- $500{ }^{\circledR}$ lineage. The birds were raised in three climate chambers, consisting of 16 boxes, measuring $2.5 \times 1.0 \mathrm{~m}$ each. The chambers were covered with polyurethane and were equipped with a heating and refrigeration system. The birds were submitted to different rearing temperatures (Table 1) with water and
Table 1 - Environmental temperatures during the experimental period

\begin{tabular}{cccc}
\hline Age (days) & \multicolumn{2}{c}{ Environmental temperature $\left({ }^{\circ} \mathrm{C}\right)$} \\
\cline { 2 - 4 } & Hot & Comfort & \multicolumn{1}{c}{ Cold } \\
\hline 1 a 3 & $35 \pm 1^{1}$ & $32 \pm 2$ & $28 \pm 3$ \\
4 a 7 & $34 \pm 1$ & $31 \pm 1$ & $26 \pm 2$ \\
8 a 14 & $32 \pm 3$ & $28 \pm 2$ & $22 \pm 2$ \\
15 a 21 & $31 \pm 3$ & $26 \pm 2$ & $20 \pm 3$ \\
22 a 42 & $30 \pm 3$ & $23 \pm 2$ & $19.5 \pm 2$ \\
\hline
\end{tabular}

${ }^{1}$ Each value represents mean \pm standard deviation of the mean

feed ad libitum throughout the experimental period of 42 days.

The birds were vaccinated against Marek disease in the incubator house, against Gumboro (intermediate Lukert cepa) and Newcastle (La Sota estirpe) at 8 days and against Gumboro disease (Australia V-877 strong cepa) at 18 days. A light program of 24 hours was used.

Feed with or without the addition of yeast extract and prebiotic was offered only in the pre-initial phase ( 1 to 7 days). From the eighth day on, every bird received the same feed (Table 2), readjusted according to each rearing phase ( 1 to $7 ; 8$ to 21 and 22 to 42 days), meeting the recommendations by Rostagno et al. (2000). Levels of yeast extract (2\%) and prebiotic $(0.15 \%)$ followed the recommendations of the manufacturer of the products.

A randomized complete experimental design was used in a $3 \times 2 \times 2$ factorial arrangement, consisting of three rearing temperatures (hot, comfort, cold), levels of yeast extract (with or without) and prebiotic levels (with or without), in four replications of 30 birds per box in each climate chamber.

The chicken performance was evaluated by weight gain (WG), feed intake (FI), food conversion (FC) and broiler rearing viability $(\mathrm{RV} \%)$ at 42 days of age. Feed intake was calculated from the difference between the weight of the feed offered and the leftovers in the troughs of the experimental units, also considering the mortalities in order to calculate each experimental unit.

At 42 days of age, four chickens from each replication were randomly selected, identified, numbered and submitted to 8 hours of fasting, weighed and processed, according to the normal procedures of stunning, slaughtering, plucking and evisceration. Carcasses were weighed with feet, neck and head, edible viscera and abdominal fat. Carcass yield was calculated based on live weight prior to slaughter and the yields of breast and whole leg (drumstick + thigh) were calculated based on carcass weight.

Two chickens from each replication were sacrificed at 42 days of age, after 12 hours fasting, to remove an empty gastrointestinal tract and to analyze the morphometric 
Table 2 - Percentage, chemical and energetic composition of the experimental feed in the phases 1 to 7,8 to 21 and 22 to 42 days of age

\begin{tabular}{|c|c|c|c|c|c|c|}
\hline \multirow[t]{3}{*}{ Ingredient } & \multicolumn{4}{|c|}{ Phase } & \multirow{3}{*}{8 to 21 days } & \multirow{3}{*}{22 to 42 days } \\
\hline & \multicolumn{4}{|c|}{1 to 7 days } & & \\
\hline & 1 & 2 & 3 & 4 & & \\
\hline Soybean bran & 39.19 & 37.03 & 39.16 & 37.03 & 36.63 & 31.14 \\
\hline Dicalcium phosphate & 1.94 & 1.96 & 1.93 & 1.95 & 1.84 & 1.862 \\
\hline Limestone & 0.93 & 0.87 & 0.87 & 0.87 & 0.87 & 0.83 \\
\hline Mineral and vitamin supplementation & $0.50^{1}$ & $0.50^{1}$ & $0.50^{1}$ & $0.50^{1}$ & $0.50^{2}$ & $0.50^{3}$ \\
\hline DL-methionine $(99 \%)$ & 0.39 & 0.42 & 0.38 & 0.41 & 0.27 & 0.21 \\
\hline L-lysine $(78 \%)$ & 0.37 & 0.45 & 0.37 & 0.45 & 0.21 & 0.23 \\
\hline Antioxidant & 0.05 & 0.05 & 0.05 & 0.05 & 0.05 & 0.05 \\
\hline Inert material & - & 0.10 & - & - & - & - \\
\hline Yeast extract ${ }^{4}$ & - & 2.00 & - & 2.00 & - & - \\
\hline Gross protein $(\%)$ & 21.11 & 21.14 & 21.11 & 21.11 & 21.14 & 19.20 \\
\hline Digestible lysine $(\%)$ & 1.33 & 1.33 & 1.33 & 1.33 & 1.15 & 1.00 \\
\hline Digestible methionine $(\%)$ & 0.52 & 0.52 & 0.52 & 0.52 & 0.45 & 0.41 \\
\hline Digestible methionine + cystine $(\%)$ & 0.94 & 0.94 & 0.94 & 0.94 & 0.82 & 0.72 \\
\hline Calcium $(\%)$ & 0.94 & 0.92 & 0.92 & 0.92 & 0.90 & 0.81 \\
\hline Available phosphorous (\%) & 0.47 & 0.47 & 0.47 & 0.47 & 0.45 & 0.40 \\
\hline Sodium $(\%)$ & 0.21 & 0.21 & 0.21 & 0.21 & 0.19 & 0.19 \\
\hline
\end{tabular}

${ }^{1}$ Mineral and vitamin suplementation. Composition/kg: Se, 54,6 mg; Cu, 25.000 mg; calcium pantothenate, 1.900; Mn, 15.252 mg; I, 260 mg; Zn, 18.250 mg; nicotinic acid, $6.930 \mathrm{mg}$; biotin, $32 \mathrm{mg}$; DL-methionine, $340 \mathrm{~g}$; choline, $120 \mathrm{~g}$; vit. A, $1.400 .000 \mathrm{UI}$; vit. B1, $356 \mathrm{mg}$; vit. B12, $2.000 \mathrm{mcg}$; vit. B2, $1.920 \mathrm{mg}$; vit. B6, $693 \mathrm{mg}$; vit. D3, 600.000 ; vit. E, $5.000 \mathrm{mg}$; vit. K, $196 \mathrm{mg}$; antioxidant, $100 \mathrm{mg}$.

$2=$ Mineral and vitamin suplementation ${ }^{1}+$ anticoccidial $25.000 \mathrm{mg}$ and growth promoter $10.000 \mathrm{mg}$.

3 from 35 to 42 days $=$ Mineral and vitamin suplementation ${ }^{1}+$ growth promoter $10.000 \mathrm{mg}$.

${ }^{4} \mathrm{NuPro}^{\circledR}$ : Alltech Agroindustrial from Brazil Ltda. Araucária, Paraná.

5 Bio-Mos ${ }^{\circledR}$ : Alltech Agroindustrial from Brazil Ltda. Araucária, Paraná.

intestinal parameters. Samples approximately $2 \mathrm{~cm}$ long were removed from the medial region of each chicken, of the duodenum, jejunum and ileum of the small intestine. Fragments were opened longitudinally, removed and fixed immediately in Bouin solution for 24 hours. The samples were then washed in $70 \%$ alcohol to remove the fixing solution, dehydrated in increasing alcohol series, clarified in xylol and embedded in paraffin. Semi-seriated $5 \mu \mathrm{m}$ thick histological cuts were made, that were stained with hematoxilin-eosin, according to methodology by Behmer et al. (1976), and the microscope slides were assembled with Canada balsam. In order to asses the morphometric analyses of the histological microscope slides of the intestinal mucosa, the program Image $J^{\circledR}$ (Rasband, 2004) was used to capture the images and to measure the villus height and crypt depth, with 64 readings/intestinal region/variable.

Intestinal samples were also collected from one of the chickens used for analysis in light field microscopy and for scanning electron microscopy study, a process performed in each replication. Fragments of approximately
$2 \mathrm{~cm}$ of each segment had their intestinal content removed with phosphate buffer $0.01 \mathrm{M}$ and $\mathrm{pH}$ 7.4. Samples were fixed in $2.5 \%$ glutaraldehyde in phosphate buffer, for 24 hours at $4^{\circ} \mathrm{C}$. After fixing, the fragments were washed again with the same buffer and post-fixed with osmium tetroxide at $1 \%$ in phosphate buffer for 2 hours. Samples were washed again in the same buffer solution and dehydrated in increasing alcohol series $(30,50,70,80,90$ and $100 \%)$. After achieving the critical point of dryness, using $\mathrm{CO}_{2}$, the fragments were coated in gold and photographed in a scanning electron microscope (model: JEOL JSM $\left.25 \mathrm{SII}^{\circledR}\right)$. The average number of villus/area/ chicken was obtained by counting of the number of villi in three electron micrography/segment/chicken, where each area was equal to $117,673 \mu \mathrm{m}^{2}$.

Data was submitted to analysis of variance by the GLM procedure in the $\mathrm{SAS}^{\circledR}$ program (SAS, 2002) and, in case of significant difference, means were compared to determine the carcass and cuts yields and the morphometric analyses by Tukey test (5\%) and for the other variables the Duncan or Fisher test (5\%) were used. 


\section{Results and Discussion}

There was significant interaction only between temperature and prebiotic in feed for weight gain $(\mathrm{P}=0.0273)$ and between temperature and yeast extract for food conversion ( $\mathrm{P}=0.0267)$ (Tables 3 and 4 , respectively). Prebiotic had significant effect only in the hot environment, a condition that provided greater weight gain at 42 days of age, when it was $5.33 \%$ greater than the weight gain obtained with feed without the inclusion of prebiotic (Table 3). This fact may be related to the higher villus height in the duodenum of chickens raised under this temperature that increased the absorption surface and provided a better use of the food (Figure 1).

When the effect of the prebiotic on temperature was evaluated, it was observed that when prebiotic was offered, weight gain was higher in the cold environment, followed by the comfort and hot environments, which did not differ statistically. The weight gain of chickens raised in this environment was on average $4.15 \%$ higher than that of chickens raised in the other temperatures. Greater weight gain in cold with the inclusion of prebiotic may be justified by the higher villus height in the duodenum and jejunum (Figure 1) and by a greater villus density in the jejunum, which provides a larger absorption area, increases weight gain, due to a better use of the food. However, in absence

Table 3 - Development of the interaction between environmental temperature and prebiotic for weight gain ( $\mathrm{g}$ ) of broiler chickens in the period from 1 to 42 days of age

\begin{tabular}{lccc}
\hline Temperature & \multicolumn{2}{c}{ Prebiotic } & Probability \\
\cline { 2 - 3 } & With & Without & \\
\hline Hot & $2,666 \mathrm{Ab}$ & $2,524 \mathrm{Bc}$ & 0.0020 \\
Comfort & $2,656 \mathrm{~b}$ & $2,654 \mathrm{~b}$ & $\mathrm{NS}$ \\
Cold & $2,771 \mathrm{a}$ & $2,795 \mathrm{a}$ & $\mathrm{NS}$ \\
Probability & 0.0145 & $<0.0001$ & \\
\hline
\end{tabular}

Means followed by the same lowercase (uppercase) letters at column (line) do not differ $(\mathrm{P}>0.05)$ according to the Fisher and Tukey tests.

$\mathrm{NS}=$ not significant

Table 4 - Development of the interaction between environmental temperature and yeast extract for food conversion of broiler chickens in the period from 1 to 42 days of age

\begin{tabular}{lccc}
\hline Temperature & \multicolumn{2}{c}{ Yeast extract } & Probability \\
\cline { 2 - 3 } & With & Without & \\
\hline Hot & $1.58 \mathrm{a}$ & $1.61 \mathrm{a}$ & $\mathrm{NS}$ \\
Comfort & $1.71 \mathrm{~b}$ & $1.70 \mathrm{~b}$ & $\mathrm{NS}$ \\
Cold & $1.71 \mathrm{Bb}$ & $1.65 \mathrm{Aab}$ & 0.0436 \\
Probability & $<0.0001$ & 0.0042 & \\
\hline
\end{tabular}

Means followed by same lowercase (uppercase) letters in column (line) did not differ $(\mathrm{P}>0.05)$ according to the Fisher and Tukey tests

$\mathrm{NS}=$ not significant of prebiotic, weight gain was also higher in the cold environment, followed by the comfort and hot environments. In the cold environment, weight gain was $5.04 \%$ and $9.69 \%$ higher than in the chickens raised in the comfort and heat environments, respectively. Greater weight gain in the cold may be caused by the increase in the feed intake, as a mechanism to compensate the higher heat loss (Close \& Mount, 1978). As counterpart, the lower weight gain in the hot environment happened due to less feed intake, as a defense mechanism to reduce heat production. Even if the animal produces heat by maintenance metabolism and possibly by the catabolism of some tissue, the heat generated by digestion and deposition in tissue is reduced. In addition, the villus height in the duodenum and jejunum of chickens fed diets without prebiotic was lower, despite the greater villus density found at this temperature.

Environmental temperature influenced food conversion (Table 4) at each level of yeast extract. The effect of cold temperature was more pronounced in the absence of yeast extract in the pre-initial feed, which provided better food conversion at the end of broiler raising. This fact may be related to greater villus height in the jejunum in the absence of yeast extract in the pre-initial feed (Figure 1).

When evaluating the inclusion of yeast extract at different temperatures, the worst food conversion was observed in the comfort and cold environments and the best was observed in the hot environment, but there were no difference between the results obtained in the cold and at other temperatures. The best food conversion in the hot environment occurred because of low food consumption and greater weight gain that resulted in better food conversion at that age. However, according to Abu-Dieyeh (2006), high temperature per se induces physiological changes in chickens with the decrease in metabolic rate, which results in less food intake and deficient digestion that impairs metabolism.

There was no interaction $(\mathrm{P}>0.05)$ of the results of feed intake, food conversion, rearing viability, carcass yield, breast percentage and whole leg percentage (Table 5).

Feed intake was lower in the hot environment compared to the comfort environment ( $\mathrm{P}>0.0001)$, that, in turn, presented lower feed intake than in the cold environment (Table 5). Broiler chickens raised under hot temperatures consumed $9 \%$ less feed compared to those raised in the comfort environment. This occurred because, as feed intake increases the total heat production increases accordingly (Koh \& Mcleod, 1999 a,b; Longo et al., 2006), and that increases the amount of heat received by the 

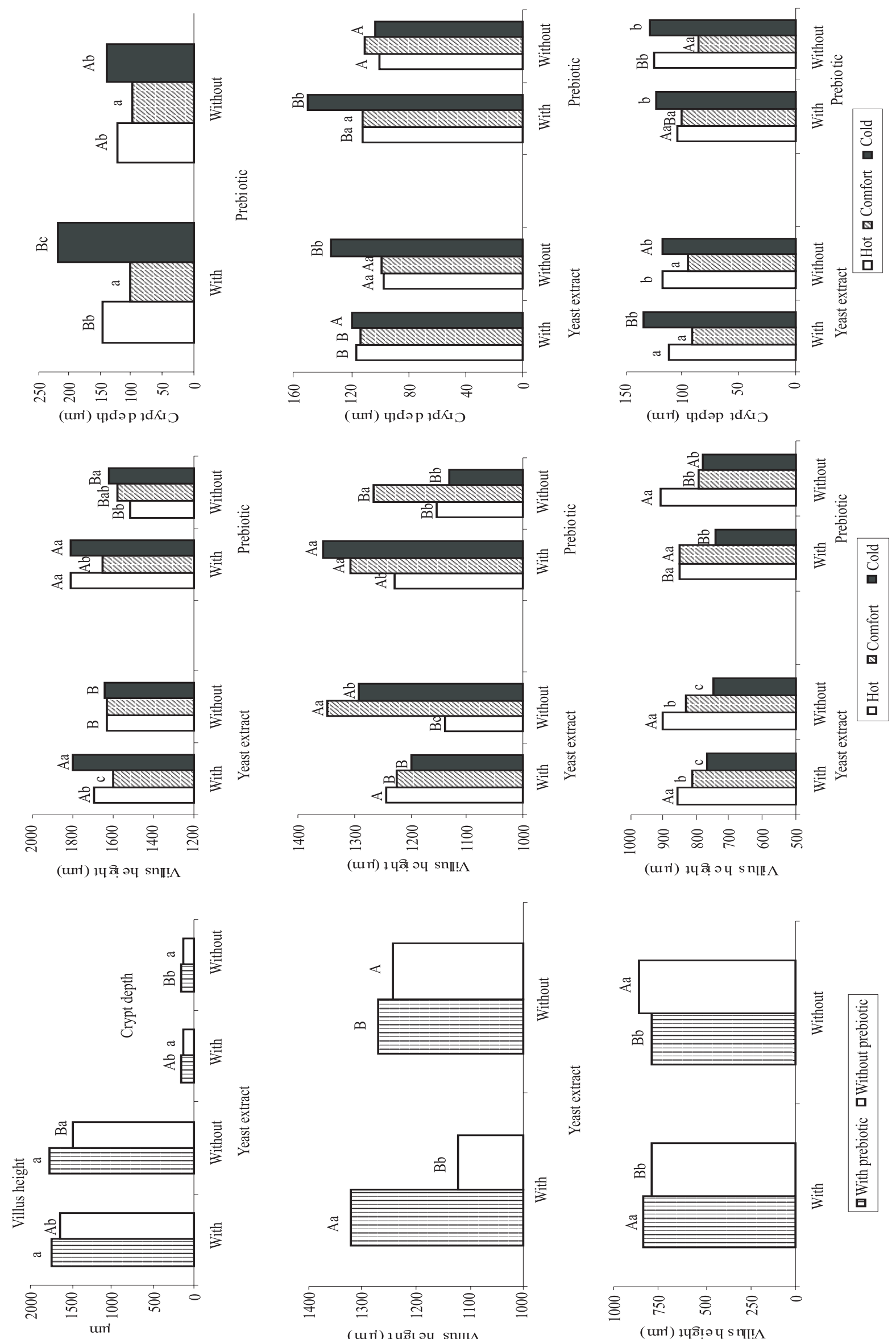

unuəponब
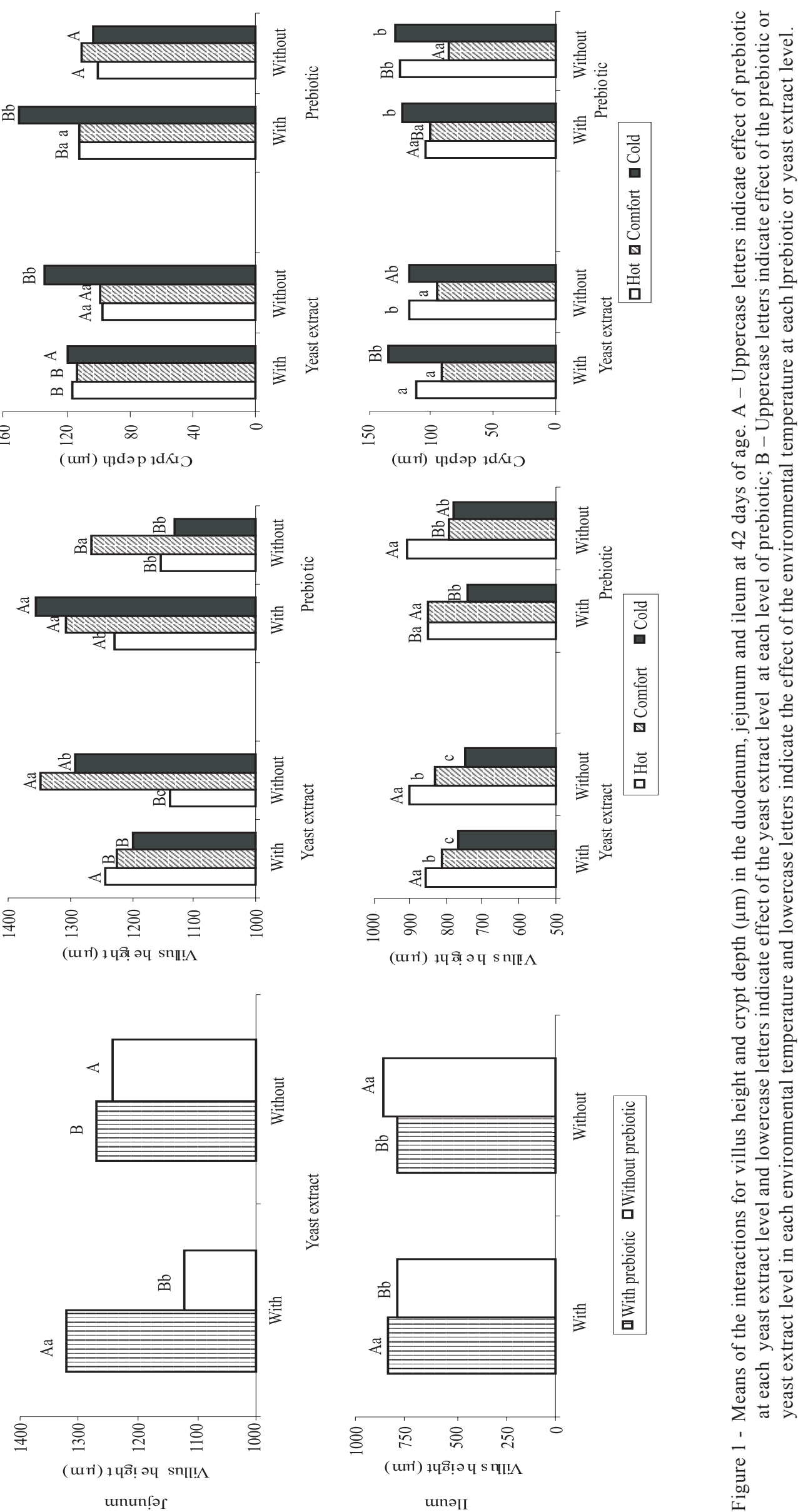

R. Bras. Zootec., v.39, n.1, p.165-174, 2010 
Table 5 - Performance indexes of broiler chickens fed diets supplemented or not with yeast extract and prebiotic reared under different temperatures in the period from 1 to 42 days of age

\begin{tabular}{|c|c|c|c|c|c|}
\hline & Feed intake $(\mathrm{g})$ & Viability (\%) & Carcass yield $(\%)$ & Breast $(\%)$ & Whole leg (drumstick + thigh) $(\%)$ \\
\hline \multicolumn{6}{|c|}{ Temperature $^{1}$} \\
\hline Hot & $4,134 \mathrm{c}$ & 92.91 & $84.25 \mathrm{a}$ & $31.42 \mathrm{ab}$ & $27.58 \mathrm{a}$ \\
\hline Comfort & $4,507 \mathrm{~b}$ & 95.00 & $83.80 \mathrm{~b}$ & $31.60 \mathrm{a}$ & $26.79 b$ \\
\hline \multicolumn{6}{|c|}{ Prebiotic $^{2}$} \\
\hline With & $4,474 a$ & 95.41 & 83.00 & 31.47 & 27.04 \\
\hline With & 4,410 & 93.05 & 83.12 & 31.31 & 26.82 \\
\hline Without & 4,468 & 94.44 & 83.01 & 31.45 & 27.14 \\
\hline
\end{tabular}

${ }_{2}^{1}$ Means followed by the same letters in the same column do not indicate statistical differences $(\mathrm{P}>0.05)$ according to the Duncan test.

2 Means followed by the same letters in the same column do not indicate statistical differences $(\mathrm{P}>0.05)$ according to the Fisher test.

animal, aggravating the caloric stress. When in a cold environment, chickens presented a $4 \%$ feed intake increase compared to the comfort environment, since when feed intake increases, heat production also increases, reducing the stress caused by cold.

None of the studied features affected the rearing viability in the 1 to 42 days of age phase $(\mathrm{P}>0.05)$. However, rearing viability was influenced by the inclusion of prebiotic in the diet of the phases 1 to 7 and 1 to 21 days of age. This beneficial effect may have been related to the small diversity of intestinal microflora of newborn chicks, because besides being considered a limiting factor for digestion, this also makes possible the intestinal colonization by enteric pathogens. The absence of contact with the natural microbiota prior to birth may affect the development of the gastrointestinal tract and impair the growth of chickens. Ito et al. (2004) described that, from the third day of the chick's life, desirable microorganisms, such as Lactobacillus and others from the normal gastrointestinal microbiota, are found in large amounts in the intestinal medium. Nevertheless, the occurrence of greater challenges in environmental morbid situations may make the flora unstable until the $5^{\text {th }}$ week of the bird life (Canalli et al., 1996). With the intestinal microbiota in equilibrium, birds had better conditions for absorbing nutrients and could confront, in better conditions, the stress in that production phase. Also, there was no influence of the yeast extract on weight gain, which is in agreement with results reported by Santos et al. (2005) who also did not observe the effect of prebiotics and organic acid on the performance of broiler chickens.

Only the environmental temperature affected the carcass yield ( $\mathrm{P}=0.0003)$, breast $(\mathrm{P}=0.0469)$ and whole leg $(\mathrm{P}=0.0006)$ of the chickens. Carcass and whole leg yield swere greater in the hot than in the comfort and cold environments, with means $3.1 \%$ greater for carcass yield and $1 \%$ superior for whole leg yield (Table 5). The better carcass yield in the hot environment may have occurred because of the lower visceral development of birds reared at this temperature, due to the lower metabolism of the birds (Machado, 2001), the lower feather coverage, caused by the great need to dissipate heat (Geraert et al., 1996a; Cooper \& Washburn, 1998), and to the greater deposition of abdominal fat (Howlider \& Rose, 1987; Furlan et al., 2001). However, the higher carcass yield was not compensated by the higher body weight and by the better food conversion of birds reared in the hot environment.

Whole leg yield was greater in the birds $(\mathrm{P}=0.0006)$ in the hot environment, which may be explained by the oxidative metabolism in these muscles, because birds exposed to high temperatures require a higher concentration of plasmatic glucose that increases the oxidative metabolism and favors energy storage as fat in the whole leg (Geraert et al; 1996a,b; Faria Filho et al., 2006).

Breast yield was affected only by environmental temperature $(\mathrm{P}=0.0469)$ and was greater in the comfort environment, on average, $1 \%$ greater, and lower in the cold environment. Whereas in the hot environment the breast yield did not differ from those found in the comfort and cold environments. These results are in accordance with those reported by Perrault \& Lesson (1992) and by Costa et al. (2001). However, they do not agree with the results presented by Baziz et al. (1996), Yalçin et al. (2001) and Faria Filho et al. (2006) where the lower breast yield in high temperatures was due to an increase in panting during heat stress that reflected in more activity of the pectoral girdle muscles, causing the breakdown of glycogen stored in these muscles, and thus impairing its yield. It is possible that the results found for breast yield may be related to the influence of hot and cold 
environments since the first day of life, because in those experiments, birds were raised under high temperatures after 21 days of age. On the other hand, the effect caused by cold was inverse, because, as it is known, birds need high temperatures in their first days of life in order to maintain homeothermy but, in this experiment the stress caused by cold since the first day of life may be reflected within the first 42 days of life, resulting in lower breast yield.

Only the interactions between the environmental temperature and yeast extract for crypt depth in the duodenum, and between the prebiotic and yeast extract for crypt depth in the jejunum and ileum were not significant (Table 6).

The remaining effect of including prebiotic and yeast extract in the pre-initial feed was not enough to prevent the larger crypt depth found in the ileum at 42 days of age $(\mathrm{P}>0.05)$, probably because of an imbalance between two cellular renewal process - proliferation and differentiation (Figure 1), as a result of mitotic divisions of totipotent cells located in the crypt and along the villus (Uni et al., 1998).

It is known that, as the intestinal villi are destroyed, there is an attempt to repair the mucosa through the process of proliferation/mitosis in the crypt, determining deeper crypts (Blikslager \& Roberts, 1997; Luquetti et al., 2006). According to Yason et al. (1987) and Pluske et al. (1997), higher values of crypt depth indicate more proliferative cell function to guarantee a suitable rate of epithelial renewal and high demand for new tissue. Nevertheless, data in the present study disagree from those reported by Bradley et al. (1994), who, when studying diet supplementation for broilers with $0.02 \%$ S. cerevisae observed a decrease in crypt depth in the ileum and suggested that the use of $S$. cerevisae reduced the stress conditions to which the mucosa is submitted and reduced the number of bacteria and toxins in the intestine.

Thermal stress caused by heat probably contributed to altering the release of thyroidal hormones that have enterotrophic action, as a stimulus for intestinal mucosa growth (Mitchell \& Carlisle, 1992). Thus, functional hypothyroidism induced by caloric stress may be involved in the reduction of villus height in the duodenum $(\mathrm{P}>0.0001)$ and jejunum $(\mathrm{P}>0.0001)$ at 42 days. Few studies were found in the literature on the influence of temperature on intestinal morphometry.

Only the interactions between the environmental temperature and yeast extract for the duodenum and between prebiotic and yeast extract for the duodenum and ileum were not significant $(\mathrm{P}>0.05)$ (Table 7).

The influence of the temperature on villus density at 42 days of age was probably related to the stress level of the animal that also could influence the biological response obtained by adding prebiotics to the $\operatorname{diet}$ (Tables 8,9 and 10). If the animals are kept in no-stress conditions, it is

Table 7 - Villus density of broiler chickens at 42 days of age

\begin{tabular}{lcccc}
\hline & & Duodenum & Jejunum & Ileum \\
\hline Environmental & & & & \\
Temperature $^{1}$ & Hot & $23.90^{3}$ & $32.89^{3}$ & $42.34 \mathrm{~b}^{3}$ \\
& Comfort & 21.92 & 30.41 & $45.65 \mathrm{~b}$ \\
& Cold & 18.93 & 36.09 & $57.38 \mathrm{a}$ \\
Prebiotic $^{2}$ & & & & \\
& With & 21.09 & 33.48 & $50.65 \mathrm{a}$ \\
& Without & 22.01 & 32.79 & $45.39 \mathrm{~b}$ \\
Yeast extract $^{2}$ & & & & \\
& With & $25.45 \mathrm{a}$ & 32.89 & $49.57 \mathrm{a}$ \\
& Without & $14.83 \mathrm{~b}$ & 33.37 & $46.73 \mathrm{~b}$ \\
\hline
\end{tabular}

${ }^{1}$ Means followed by the same letters in the same column do not indicate statistical differences $(\mathrm{P}>0.05)$ according to the Duncan test.

2 Means followed by the same letters in the same column do not indicate statistical differences $(\mathrm{P}>0.05)$ according to the Fisher tests.

${ }^{3}$ Values expressed in number of villus $/ \mu \mathrm{m}^{2}$

Table 6 - Average values of villus height and crypt depth of broiler chickens fed diets supplemented or not with yeast extract and prebiotic and reared under different temperatures at 42 days of age

\begin{tabular}{|c|c|c|c|c|c|c|}
\hline & \multicolumn{2}{|c|}{ Duodenum $(\mu \mathrm{m})$} & \multicolumn{2}{|c|}{ Jejunum $(\mu \mathrm{m})$} & \multicolumn{2}{|c|}{ Ileum $(\mu \mathrm{m})$} \\
\hline & Villus height & Crypt depth & Villus height & Crypt depth & Villus height & Crypt depth \\
\hline \multicolumn{7}{|c|}{ Temperature $^{1}$} \\
\hline Comfort & $1614 \mathrm{c}$ & $101 \mathrm{c}$ & $1285 \mathrm{a}$ & $106 b$ & $818 b$ & $93 \mathrm{c}$ \\
\hline Cold & $1719 a$ & $179 a$ & $1245 b$ & $127 \mathrm{a}$ & $759 c$ & $126 a$ \\
\hline \multicolumn{7}{|l|}{ Prebiotic ${ }^{2}$} \\
\hline \multicolumn{7}{|c|}{ Yeast extract ${ }^{2}$} \\
\hline With & $1699 a$ & $156 \mathrm{a}$ & $1222 b$ & $116 \mathrm{a}$ & 812 & 112 \\
\hline Without & $1631 \mathrm{~b}$ & $120 \mathrm{~b}$ & $1258 \mathrm{a}$ & $110 \mathrm{~b}$ & 827 & 110 \\
\hline
\end{tabular}

\footnotetext{
${ }^{1}$ Means followed by the same letters in the same column do not indicate statistical difference $(\mathrm{P}>0.05)$ according to the Duncan test.
}

${ }^{2}$ Means followed by the same letters in the same column do not indicate statistical difference $(\mathrm{P}>0.05)$ according to the Fisher test. 
Table 8 - Development of the interaction between temperature and prebiotic for villus density in the duodenum of broiler chickens at 42 days of age

\begin{tabular}{lccc}
\hline Temperature & \multicolumn{2}{c}{ Prebiotic } & Probability \\
\cline { 2 - 3 } & With & Without & \\
\hline Hot & 21.17 & $26.64 \mathrm{a}$ & NS \\
Comfort & 20.53 & $23.31 \mathrm{a}$ & NS \\
Cold & 21.77 & $16.08 \mathrm{~b}$ & NS \\
Probability & NS & 0,0304 & \\
\hline
\end{tabular}

In the same column, means followed by the same letters do not indicate statistical differences $(\mathrm{P}>0.05)$ according to the Tukey test.

Values expressed in number of villus/micrometer ${ }^{2}$

$\mathrm{NS}=$ not significant

Table 9 - Development of the interaction for villus density in the jejunum of broiler chickens at 42 days of age

\begin{tabular}{|c|c|c|c|}
\hline \multirow[t]{2}{*}{ Prebiotic } & \multicolumn{2}{|c|}{ Yeast extract } & \multirow[t]{2}{*}{ Probability } \\
\hline & With & Without & \\
\hline With & $37.30 \mathrm{Aa}$ & $29.65 \mathrm{Bb}$ & 0.0119 \\
\hline Without & $28.47 \mathrm{Bb}$ & $37.10 \mathrm{Aa}$ & 0.0051 \\
\hline Probability & 0.0042 & 0.0142 & \\
\hline \multirow[t]{2}{*}{ Temperature } & \multicolumn{2}{|c|}{ Yeast extract } & Probability \\
\hline & With & Without & \\
\hline Hot & $28.25 \mathrm{Bb}$ & $37.54 \mathrm{Aa}$ & 0.0126 \\
\hline Comfort & $30.62 \mathrm{~b}$ & $30.18 \mathrm{~b}$ & NS \\
\hline Cold & $39.79 \mathrm{Aa}$ & $32.39 \mathrm{Bab}$ & 0.0436 \\
\hline Probability & 0.0024 & 0.0448 & \\
\hline \multirow[t]{2}{*}{ Temperature } & \multicolumn{2}{|c|}{ Prebiotic } & Probability \\
\hline & With & Without & \\
\hline Hot & $27.29 \mathrm{Bb}$ & $38.50 \mathrm{Aa}$ & 0.0031 \\
\hline Comfort & $30.88 \mathrm{~B}$ & $29.92 \mathrm{~B}$ & NS \\
\hline Cold & $42.25 \mathrm{Aa}$ & $29.93 \mathrm{Bb}$ & 0.0013 \\
\hline Probability & 0.0002 & 0.0207 & \\
\hline
\end{tabular}

Means followed by the same lowercase (uppercase) letters in column (line) do not differ $(\mathrm{P}>0.05)$ according to the Fisher and Tukey tests, respectively. NS $=$ not significant

Values expressed in number of villus $/ \mu \mathrm{m}^{2}$

Table 10 - Development of the interactions for villus density in the ileum of broiler chickens at 42 days of age

\begin{tabular}{|c|c|c|c|}
\hline \multirow[t]{2}{*}{ Temperature } & \multicolumn{2}{|c|}{ Prebiotic } & \multirow[t]{2}{*}{ Probability } \\
\hline & With & Without & \\
\hline Hot & $41.82 b$ & $41.88 \mathrm{~b}$ & NS \\
\hline Comfort & $53.66 \mathrm{Aa}$ & $37.64 \mathrm{Bc}$ & $<0.0001$ \\
\hline Cold & $57.35 \mathrm{a}$ & $57.42 \mathrm{a}$ & NS \\
\hline Probability & $<0.0001$ & $<0.0001$ & \\
\hline \multirow[t]{2}{*}{ Temperature } & \multicolumn{2}{|c|}{ Yeast extract } & Probability \\
\hline & With & Without & \\
\hline Hot & $39.44 \mathrm{Bb}$ & $45.25 \mathrm{Ab}$ & 0.0272 \\
\hline Comfort & $54.77 \mathrm{Aa}$ & $36.52 \mathrm{Bc}$ & $<0.0001$ \\
\hline Cold & $56.35 \mathrm{a}$ & $58.41 \mathrm{a}$ & NS \\
\hline Probability & $<0.0001$ & $<0.0001$ & \\
\hline
\end{tabular}

Means followed of same lowercase (uppercase) letters in column (line) do not differ according to the Fisher and Tukey tests $(\mathrm{P}>0.05)$.

NS $=$ not significant

Values expressed in number of villus $/ \mu \mathrm{m}^{2}$ supposed that the microbiota would be in equilibrium, meaning that, with or without supplying prebiotics the answers obtained would be very similar. However, when the animals are submitted to a stressing condition, supplying with prebiotics also have a benefic effect upon the biological response (Mathew, 1993).

A possible explanation for the different villus densities in the ileum (Table 10) of birds reared under cold and hot temperatures at 42 days of age would be related to thyroidal hormones, that have an enterotrophic action by stimulating intestinal mucosa growth (Levin, 1969). Therefore, functional hypothyroidism induced by thermal stress could be involved in the decrease in the number of villi in that region (Mictchell \& Carlisle, 1992). On the other hand, stress produced by cold enlarges the thyroid gland, because the functional activity of the thyroid, which is positively correlated to weight, is higher during the exposure to low temperature environments (Donkoh, 1989).

The beneficial action of the yeast extract on the villus density in the three intestinal regions was probably influenced by the thermal conditions and by the stress suffered by the animals (Table 9 and 10). When in a stress situation, alterations in the hypothalamo-hypophysealadrenal axis occur (Ballone, 2002), which reflect on hormone secretion and influence tissue development. Few data on the effect of yeast extract on villus density were found in the literature, but Uauy et al. (1990) and Ortega et al. (1995) suggested that the nucleotides may accelerate the normal physiological response to stress, but the mechanism is unknown.

\section{Conclusions}

Environmental temperature influences the performance and carcass yield that worsen in high temperature environments. The inclusion of prebiotic in pre-initial feed favors weight gain and enhances the food conversion in birds reared under high temperatures. Furthermore, it positively influences the morphometry and the villus density of the three intestinal regions evaluated; the duodenum and ileum are the regions that presents the best response under high and low temperature conditions and the jejunum is the region with the best response to the comfort temperature at 42 days of age.

\section{References}

ABU-DIEYEH, Z.H.M. Effect of high temperature per se on growth performance of broilers. International Journal of Poultry Science, v.5, n.1, p.19-21, 2006.

ALBINO, L.F.T.; FERES, F.A.; DIONIZIO,M.A. et al. Uso de prebióticos à base de mananoligossacarídeo em rações para 
frangos de corte. Revista Brasileira de Zootecnia, v.35, n.3, p.742-749, 2006

BAllone, G.J. 2002. Estresse. PsiqWeb Psiquiatria Geral. Disponível em: <http://www.psiqweb.med.br/cursos/stress1.html>. Acesso 15/5/2006.

BAZIZ, H.A.; GERAERT, P.A.; GUILLAUMIN, S. Chronic heat exposure enhances fat deposition and modifies muscle and fat partition in broiler carcasses. Poultry Science, v.75, n.4, p.505-513, 1996.

BEHMER, A.O.; TOLOSA, E.M.C.; FREITAS-NETO, A.G. Manual de técnicas para histologia normal e patológicas. 1.ed. São Paulo: EUSPE, 1976. 239p.

BLIKSLARGER, A.T.; ROBERTS, C. Mechanisms of intestinal mucosal repair. Journal American Veterinary Medicine Association, v.211, n.9, p.1437-1441, 1997.

BRADLEY, G.L.; SAVAGE, T.F.; TIMM, K.I. The effects of supplementing diets with Saccharomyces cerevisiae var. boulardii on male poultry performance and ileal morphology. Poultry Science, v.73, n.11, p.1766-1770, 1994.

CANALLI, L.S.; FLEMMING, J.S.; MIRA, R.T. et al. Alteração da microbiota intestinal de frangos de corte pela utilização de probiótico na alimentação. Revista do Setor de Ciências Agrárias, v.15, n.1, p.125-132, 1996.

CLOSE, W.H.; MOUNT, L.E. The effects of plane of nutrition and environmental temperature on the energy metabolism of the growing pig. 1. Heat loss and critical temperature. British Journal Nutrition, v.40, n.3, p.413-421, 1978.

COOPER, M.A.; WASHBURN, K.W. The relationships of body temperature to weight gain, feed consumption and feed utilization in broiler under heat stress. Poultry Science, v.77, n.3, p.237-242, 1998

COSTA, F.G.P.; ROSTAGNO, H.S.; TOLEDO, R.S. et al. Efeito da relação arginina:lisina sobre o desempenho e qualidade de carcaça de frangos de corte de 3 a 6 semanas de idade, em condições de alta temperatura. Revista Brasileira de Zootecnia, v.30, n.6, p.2021-2025, 2001.

DONKOH, A. Ambient temperature: a factor affecting performance and physiological response of broiler chickens. International Journal of Biometeorology, v.33, p.259-265, 1989.

FARIA FILHO, D.E.; ROSA, P.S.; FIGUEIREDO, D.F. et al. Dietas de baixa proteína no desempenho de frangos criados em diferentes temperaturas. Pesquisa Agropecuária Brasileira, v. 41, n. 1, p.101-106, 2006.

FURLAN, R.L.; CARVALHO, N.C.; MALHEIROS, E.B. et al. Efeito da restrição alimentar inicial e da temperatura ambiente sobre o desenvolvimento de vísceras e ganho compensatório em frangos de corte. Arquivo Brasileiro de Medicina Veterinária e Zootecnia, v.53, n.4, p.209-230, 2001.

GERAERT, P.A.; PADILHA, J.C.F.; GUILLAUMIN, S. Metabolic and endocrine changes induced by chronic heat exposure in broiler chickens: Growth performance, body composition and energy retention. British Journal of Nutrition, v.75, n.2, p. 195-204, 1996a.

GERAERT, P.A.; PADILHA, J.C.F.; GUILLAUMIN, S. Metabolic and endocrine changes induced by chronic heat exposure in broiler chickens: biological and endocrinological variables. British Poultry Nutrition, v.75, n.2, p.205-216, 1996b.

GODOI, M.J.S.; ALBINO, L.F.T.; ROSTAGNO, H.S. et al. Utilização de aditivos em rações formuladas com milho normal e de baixa qualidade para frangos de corte. Revista Brasileira de Zootecnia, v.37, n.6, p.1005-1011, 2008.

HOWLIDER, M.A.R.; ROSE, S.P. Temperature and the growth of broilers. World's Poultry Science Journal, v.43, n.10, p.228-237, 1987.

ITO, N.M.K.; MIAJI, C.I.; LIMA, A.E. et al. Saúde gastrointestinal, manejo e medidas para controlar as enfermidades gastrointestinais. In: Produção de frangos de corte, 2004. Campinas: FACTA, 2004. p.206-260.

KOH, K.; MACLEOD, M.G. Circadian variation in heat production and respiratory quotient in growing broilers maintained at different food intakes and ambient temperatures. British Poultry Science, v.40, p.353-356, 1999a.

KOH, K.; MACLEOD, M.G. Effects of ambient temperature on heat increment of feeding and energy retention in growing broilers maintained at different food intakes. British Poultry Science, v.40, n.3, p.511-516, 1999b.

LEVIN, R.J. The effects of hormones on the absorptive, metabolic and digestive functions of the small intestine. Journal Endocrinology, v.45, n.3, p.315-348, 1969.

LONGO, F.A.; SAKOMURA, N.K.; RABELLO, C.B.V. et al. Exigências energéticas para mantença e para o crescimento de frangos de corte. Revista Brasileira de Zootecnia, v.35, n.1, p.119-125, 2006.

LUQUETTI, B.C.; FARIA FILHO, D.E.; TORRES, K.A.A. et al. Effect of vaccination against coccidiosis and prebiotic supplementation in the diet on broiler performance and small intestine development. In: EUROPEAN POULTRY CONFERENCE, 12., 2006, Verona. Proceedings... Verona, 2006. p.491-492.

MACHADO, J.R.S.A. Efeito da temperatura de incubação e de criação sobre o desenvolvimento de vísceras, composição química da carcaça e morfometria intestinal de frangos. 2001. 48f. Monografia (Trabalho de Graduação em Zootecnia) - Faculdade de Ciências Agrárias e Veterinárias, Universidade Estadual Paulista, Jaboticabal.

MATHEW, A.G. Effect of galactan on selected microbial populations and $\mathrm{pH}$ and volatile fatty acids in the ileum of the weanling pig. Journal of Animal Science, v.71, n.6, p.1503-1509, 1993.

MitCHELL, M.A.; CARLiSle, A.J. The effect of chronic exposure elevated environmental temperature on intestinal morphology and nutrient absorption in the domestic fowl (Gallus domesticus). Comparative Biochemistry Physiology A, v.101, n.1, p.137-142, 1992.

OLIVEIRA, M.C.; CANCHERINI, L.C..; GRAVENA, R.A.; RIZZO, P.V.; MORAES, V.B.M.. Utilização de nutrientes de dietas contendo mananoligossacarídeo e/ou complexo enzimático para frangos de corte. Revista Brasileira de Zootecnia, v.36, n.4, p.825-831, 2007

OLIVEIRA, M.C.; CANCHERINI, L.C.; MARQUES, R.H. et al. Mananoligossacarídeos e complexo enzimático em dietas para frangos de corte. Revista Brasileira de Zootecnia, v.38, n.5, p.879-886, 2009

ORTEGA, M.A.; NUÑEZ, M.C.; GIL, A. et al. Dietary nucleotides accelerate intestinal recovery after food deprivation in old rats. Journal Nutrition, v.125, n.6, p.1413-1418, 1995.

PERRAULT, N.; LEESON, S. Effect of environmental temperature, dietary energy, and feeding level on growth carcass composition of male broiler chickens to 35 days of age. Canadian Journal Animal Science, v.72, n.4 p.695-702, 1992

PLUSKE, J.R.; WILLIANS, I.H.; AHERE, F.X. Maintenance of villous height and crypt depth in piglets by providing continuous nutrition after weaning. Animal Science, v.62, n.1, p.131-144, 1997.

RASBAND, W.S. [2004]. Image J, National Institutes of Health. Disponível em: $<$ http://rsb.info.nih.gov/ij > Acesso em: 28/5/2005.

ROSTAGNO, H.S.; ALBINO, L.F.T.; DONZELE, J.L. et al. Tabelas brasileiras para aves e suínos - Composição dos alimentos e exigências nutricionais. 2.ed. Viçosa, MG: UFV, Imprensa Universitária, 2000. 141p.

SANTOS, E.C.; TEIXEIRA A.S.; FREITAS, R.T.F. et al. Uso de aditivos promotores de crescimento sobre o desempenho, características de carcaça e bactérias totais do intestino de frangos de corte. Ciência e Agrotecnologia, v.29, n.1, p.223-231, 2005

SILVA, L.P.; NÖRNBERG, J.L. Prebióticos na nutrição de não ruminantes. Ciência Rural, v.33, n.5, p.983-990, 2003. 
SILVA, V.K.; SILVA, J.D.T.; GRAVENA, R.A. et al. Desempenho de frangos de corte de 1 a 21 dias de idade alimentados com rações contendo extrato de leveduras e prebiótico e criados em diferentes temperaturas. Revista Brasileira de Zootecnia, v.38, n.4, p.690-696, 2009.

STATISTICAL ANALYSIS SYSTEM - SAS. User's guide. Cary: SAS Institute, 2002. (CD-ROM).

UAUY, R.; STRINGEL, G.; THOMAS, R. et al. Effect of dietary nucleosides of growth and maturation of the developing gut in rat. Journal of Pediatric Gastroenterology Nutrition, v. $10, \mathrm{n} .4$, p.497-503, 1990
UNI, Z.; GANOT, S.; SKLAN, D. Post hatch development of mucosal function in the broiler small intestine. Poultry Science, v.77, n.1, p.75-82, 1998

YALÇIN, S.; ÖZKAN, S.; TÜRKMUT, L. et al. Responses to heat stress in commercial and local broiler stocks. 1. Performance traits. British Poultry Science, v.42, n.4, p.149-152, 2001

YASON, C.V.; SUMMERS, B.A.; SCHAT, K.A. Pathogenesis of rotavirus infection in various age groups of chickens and turkeys: Pathology. American Journal of Veterinary Research, v.48, n.6, p.927-938, 1987. 